\title{
Teknik Penilaian Sikap Spritual dan Sosial dalam Pendidikan Karakter di Sekolah Dasar 08 Surau Gadang Nanggalo
}

\author{
Darmansyah \\ Jurusan Tekhnologi Pendidika, Fakultas Ilmu Pendidikan, \\ Universitas Negeri Padang Padang, Indonesia \\ Email: darmansyah2013tp@gmail.com \\ Hp: 08126737438
}

\begin{abstract}
Curriculum 2013 mandated that learning process in Elementary School should be carried out with an integrated thematic approach. Despite of it is being tested this year; the implementation of an integrated thematic learning model requires serious effort and creativity of teachers with various forms of new innovations. Context analysis conducted in the SD (Elementary School) 08 Surau Gadang Nanggalo Padang as objects and implementation of product testing research grant competition revealed that teachers' understanding of the concept and implementation of assessment of spiritual and social attitudes have not been satisfied. Teachers' inappropriate competence in the evaluation of spiritual and social attitudes had negative impact on the students' achievement of first core competencies $\left(\mathrm{KI}_{1}\right)$ and second core competencies $\left(\mathrm{KI}_{2}\right)$ as they constitutes major focus in the character-based curriculum. Data of this study were collected by using interview and documentation; they were finally preceded through descriptive qualitative analysis. The results of this study reveal that there were four models of assessment that can be performed in the evaluation of spiritual attitudes and social attitudes namely (1) self evaluation, (2) observation of teachers, (3) peer assessment, and (4) daily journal.
\end{abstract}

Key Words: Technique, Evaluation, Spritual Attitude, Social Attitude, Charater

\begin{abstract}
Abstrak: Kurikulum 2013 telah mewajibkan proses pembelajaran di Sekolah Dasar dilaksanakan dengan pendekatan tema yang terintegrasi. Meskipun masih dalam tahap uji-coba tahun ini, namun implementasi model pendekatan tema yang terintegrasi menghendaki agar para guru berupaya semaksimal mungkin melalui berbagai kegiatan dan bentuk-bentuk pembelajaran baru yang inovatif. Analisis konteks yang dilaksanakan di SD 08 Surau Gadang Nanggalo Padang - sekolah tempat implementasi produk evaluasi dari penelitian hibah bersaing menemukan bahwa pemahaman guru tentang konsep dan implementasi penilaian spiritual dan sikap sosial masih rendah. Rendahnya kompetensi guru dalam mengevaluasi sikap spiritual dan socialtelah berdampak negative terhadap prsetasi belajar siswa pada kompetensi inti karena hal tersebut merupakan focus utama dalam kurikulum berbasis karakter. Data penelitian ini dikumpulkan melalui wawancara dan analisis dokumen, dan kemudian diproses dengan analisis deskriptif kualitatif. Hasil penelitian menunjukkan bahwa terdapat 4 model evaluasi yang dapat diterapkan guru dalam mengevaluasi sikap spiritual dan social siswa seperti: (1) Evaluasi mandiri; (2) Observasi guru; (3) Peer assessment; dan (4) Jurnal harian.
\end{abstract}

Kata Kunci: Teknik, Penilaian, Sikap Spritual, Sikap Sosial, Pendidikan Karakter

\section{PENDAHULUAN}

Undang-undang RI No. 20 tahun 2003 tentang Sistem Pendidikan Nasional mengamanahkan agar pendidikan tidak hanya memberi kesempatan untuk membentuk insan Indonesia yang cerdas semata, tetapi juga berkepribadian atau berkarakter, sehingga nantinya akan lahir generasi bangsa yang tumbuh berkembang dengan karakter yang bernafas nilai-nilai luhur bangsa serta agama. Tujuan yang terkandung dalam pasal I UU Sisdiknas tahun 2003 agar peserta didik secara aktif mengembangkan potensinya yaitu kekuatan spritual keagamaan, pengendalian diri, kepribadian, kecerdasan, akhlak mulia dan keterampilan. Secara hakiki empat komponen yang disebutkan pertama dari enam potensi peserta didik dalam UU Sisdiknas tersebut merupakan pengembangan karakter.

Pengembangan potensi peserta didik bernuansa karakter tersebut seharusnya men- 
dapat perhatian khusus dalam praktik pendidikan di Indonesia. Empat potensi peserta didik yang penting terkait dengan pendidikan karakter yakni kekuatan spritual keagamaan, pengendalian diri, kepribadian, dan akhlak mulia ternyata belum mendapatkan proporsi yang memadai dalam proses pembelajaran. Potensi-potensi peserta didik itu belum terintegrasikan secara optimal dalam pembelajaran, sehingga terjadi pendangkalan nilai karakter di kalangan anak dan remaja dewasa ini.

Pendidikan karakter sangat penting dan diperlukan dalam kehidupan sebagai individu, masyarakat, bangsa, dan negara. Pendidikan karakter didasarkan pada keyakinan bahwa pengembangan etika, sosial dan emosional peserta didik sama pentingnya dengan prestasi akademik. Banyak penelitian telah membuktikan dampak positif pendidikan karakter terhadap keberhasilan akademik. Dalam bulletin hasil studi Marvin Berkowitz dari University of Missouri St. Louis (2005) diungkapkan bahwa terdapat peningkatan motivasi siswa sekolah dalam meraih prestasi akademik pada sekolah-sekolah yang menerapkan pendidikan karakter. Kelas-kelas yang secara komprehensif terlibat dalam pendidikan karakter menunjukkan adanya penurunan drastis pada perilaku negatif siswa yang dapat menghambat keberhasilan akademik.

Data dan fakta tentang kasus pelanggaran moral yang dirilis media semakin mengkhawatirkan. Kasus pengaduan kekerasan terhadap anak selama 2012, sekitar 60 persen dari total pengaduan (sekitar 2.637 aduan) merupakan kasus kekerasan seksual. Selain itu tingkat pengguna narkoba di kalangan remaja di Indonesia sangat memprihatinkan. Badan Narkotika Nasional (BNN) mengungkapkan bahwa, kasus penyalahgunaan narkoba terus meningkat di kalangan remaja. Dari 2,21\% (4 juta orang) pada tahun 2010 menjadi 2,8 (sekitar 5 juta orang) pada tahun 2011. Pergaulan seks bebas yang mengakibatkan semakin meningkatnya pengidap HIV/AIDS berada pada peringkat kedua. Peringkat ketiga adalah tawuran antar pelajar. Di kota-kota besar, belakangan ini, tawuran antarpelajar semakin meningkat dibandingkan tahun sebelumnya. (Sumber:
Republika). Para ahli dan praktisi sependapat bahwa data yang dipaparkan di atas hanya sebagian kecil dari puncak gunung es kasus pelanggaran hukum dan etika yang terungkap melalui media. Sebagian besar lainnya tidak muncul ke permukaan karena berbagai sebab.

Penelitian di negara lain juga membuktikan tingginya tingkat pelanggaran hukum yang terjadi adalah akibat dari lemahnya perhatian terhadap pendidikan karakter. Dari sebuah penelitian di Amerika, 90 persen kasus pemecatan disebabkan oleh perilaku buruk seperti tidak bertanggung jawab, tidak jujur, dan hubungan interpersonal yang tidak baik. Daniel Goleman (2000) berpendapat bahwa keberhasilan seseorang di masyarakat, ternyata 80 persen dipengaruhi oleh kecerdasan emosional, dan hanya 20 persen ditentukan oleh kecerdasan otak (IQ). Anak-anak yang mempunyai masalah dalam kecerdasan emosinya, akan mengalami kesulitan belajar, bergaul dan tidak dapat mengontrol emosinya. Kecerdasarn emosional dan spiritual inilah yang memberikan kontribusi besar terhadap keberhasilan peserta didik.

\section{METODE PENELITIAN}

Penelitian ini menggunakan metode kulaitatif deskriptif dengan objek penelitian SD 08 Surau Gadang Nanggalo Padang. Hasil penelitian ini merupakan bagian dari penelitian hibah bersaing yang dilakukan tahun 2013. Data dikumpulkan dengan teknik wawancara dan studi dokumentasi. Wawancara dilakukan untuk mendapatkan informasi tentang kompetensi guru dalam melakukan evaluasi sikap spiritual dan sikap sosial peserta didik. Studi dokumentasi untuk mendalami konten dalam kurikulum 2013, tema, subtema dan tema kegiatan yang dilaksanakan dalam pembelajaran. Studi doku-mentasi juga digunakan untuk mendalami teknik evaluasi sikap spiritual dan sikap sosial. Informan utama dalam penelitian ini adalah kepala sekolah dan guru. Data diolah dengan teknik analisis kualitatif deskriptif. Data yang diperoleh berupa model penilaian sikap berdasarkan teori yang ada disandingkan dengan model penilaian yang dirancang oleh 
kemendikbud yang selanjutnya diverifikasi dan diklasifikasikan berdasarkan indikator yang ada Selanjutnya indikator-indikator tersebut dideskripsikan dalam bentuk format penilaian sikap spiritual dan sosial.

\section{Pendidikan Karakter}

Pendidikan karakter seharusnya dimulai sejak dini. Bahkan banyak ahli berpendapat pendidikan karakter harus dimulai sejak lahir. Pembentukan nilai-nilai karakter diawali dari dalam keluarga karena disinilah lingkungan pertama bagi pertumbuhan karakter anak. Sekolah Dasar juga menjadi tempat pertama bagi anak dalam mengembangkan karakternya. Para pakar berpendapat bahwa pendidikan karakter sebaiknya diterapkan sejak usia kanakkanak atau yang biasa disebut para ahli psikologi sebagai usia emas (golden age), karena usia ini terbukti sangat menentukan kemampuan anak dalam mengembangkan potensinya. Hasil penelitian menunjukkan bahwa sekitar 50\% variabilitas kecerdasan orang dewasa sudah terjadi ketika anak berusia 4 tahun. Peningkatan 30\% berikutnya terjadi pada usia 8 tahun, dan $20 \%$ sisanya pada pertengahan atau akhir dasawarsa kedua. Oleh karena itu sangat tepat jika SD dijadikan sebagai titik pangkal dalam menerapkan pendidikan karakter di sekolah.

Karakter merupakan pola pikir dan prilak u seseorang. Suyanto (2009) menyatakan bahwa karakter adalah cara berpikir dan berperilaku yang menjadi ciri khas tiap individu untuk hidup dan bekerjasama, baik dalam lingkup keluarga, masyarakat, bangsa dan negara. Individu yang berkarakter baik adalah individu yang bisa membuat keputusan dan siap mempertanggungjawabkan tiap akibat dari keputusan yang ia buat. Menurut Ki Hajar Dewantara (dalam Saryono, 2010)-tokoh pendidikan nasional Indonesia yang sangat terkemuka-karakter atau watak adalah paduan segala tabiat manusia yang bersifat tetap sehingga menjadi tanda yang khusus untuk membedakan orang yang satu dengan yang lain. Dijelaskan pula bahwa karakter itu merupakan "imbangan antara hidup batin seseorang dengan segala perbuatan lahirnya". Karakter akan menjadi pedoman hidup seseorang yang diwujudkan dalam bentuk sifat atau perangai khusus setiap manusia.

Dennis Coon dalam bukunya Introduction to Psychology: Exploration and Aplication (dalam Wibowo:2013) mendefinisikan karakter sebagai suatu penilaian subyektif terhadap kepribadian seseorang yang berkaitan dengan atribut kepribadian yang dapat atau tidak dapat diterima oleh masyarakat. Karakter adalah jawaban mutlak untuk menciptakan kehidupan yang lebih baik di dalam masyarakat. Definisi ini lebih mengarah pada bagaimana kualitas prilaku seseorang yang tampak dari luar melalui penilaian orang lain. Meski penilaian orang lain bersifat subjektif, namun prilaku adalah yang tampak berdasarkan karakteristik kepribadian, moral dan etika seseoarang.

Suyanto (2009) menyatakan bahwa terdapat sembilan pilar karakter yang berasal dari nilai-nilai luhur universal, yaitu (1) karakter cinta Tuhan dan segenap ciptaan-Nya; (2) kemandirian dan tanggung jawab; (3) kejujuran/ amanah, diplomatis; (3) hormat dan santun; (5) dermawan, suka tolong-menolong dan gotong royong/kerjasama; (4) percaya diri dan pekerja keras; (7) kepemimpinan dan keadilan; (8) baik dan rendah hati, dan; (9) karakter toleransi, kedamaian, dan kesatuan.

Kemendikbud (2011) menurunkan kebijakan untuk menerapkan 18 nilai karakter yang harus masuk ke dalam pembelajaran adalah; (1) Religius, (2) Jujur, (3) Toleransi, (4) Disiplin, (5) Kerja Keras, (6) Kreatif, (7) Mandiri, (8) Demokratis, (9) Rasa Ingin Tahun, (10) Semangat Kebangsaan, (11) Cinta Tanah Air (12) Menghargai Prestasi, (13) Bersahabat/ Komunikatif, (14) Cinta Damai, (15) Gemar Membaca, (16) Peduli Lingkungan, (17) Peduli Sosial, dan (18) Tanggung Jawab.

Berdasarkan dua pendapat di atas secara substantif tidak berbeda. Perbedaan hanya terlihat pada cara mengelompokkan. Karakter "cinta Tuhan" ada pada pendapat pertama sementara istilah yang digunakan pada pendapat kedua adalah "religius". Keduanya memiliki makna yang sama. Dalam penelitian ini karakter yang dijadikan sasaran adalah pendapat kedua yang dianggap lebih komprehensif dan lebih 
rinci, sehingga mudah dievaluasi. Kedelapan belas karakter inilah nanti yang akan dijadikan sasaran dalam pendidikan karakter.

Lickona (2007) mendefinisikan pendidikan karakter secara menyeluruh mencakup pemikiran, perasaan, dan perilaku. Menurutnya, pendidikan karakter adalah usaha sengaja untuk membantu orang memahami, peduli, dan bertindak berdasarkan nilai-nilai etika. Pendidikan karakter ini adalah proses pembelajaran yang memungkinkan peserta didik dalam komunitas sekolah untuk memahami, peduli dan bertindak atas nilai-nilai etika inti seperti rasa hormat, keadilan, kebajikan sipil dan kewarganegaraan, dan tanggung jawab untuk diri sendiri dan orang lain.Pendidikan karakter adalah upaya untuk melakukan internalisasi sikap dan prilaku terpuji sesuai dengan normanorma. Suyanto (2009) menyatakan pendidikan karakter adalah pendidikan budi pekerti plus, yaitu pendidikan yang melibatkan aspek pengetahuan (cognitive), perasaan (feeling), dan tindakan (action).

Joseph Zins, et.al, (2001) mengkompilasikan berbagai hasil penelitian tentang pengaruh positif kecerdasan emosi anak terhadap keberhasilan di sekolah. Dikatakan bahwa ada sederet faktor resiko penyebab kegagalan anak di sekolah. Faktor-faktor resiko yang disebutkan ternyata bukan terletak pada kecerdasan otak, tetapi pada karakter, yaitu rasa percaya diri, kemampuan bekerja sama, kemampuan bergaul, kemampuan berkonsentrasi, rasa empati, dan kemampuan berkomunikasi. Sebuah hasil survei di Nebraska yang dimuat dalam jurnal oleh Susan, dkk (2004) menunjukkan bahwa pendidi-kan karakter telah memberikan perbedaan dalam kehidupan siswa. Sebanyak $85 \%$ dila-porkan memiliki prilaku positif secara keseluruhan pada anak-anak yang diajarkan tentang karakter, $73 \%$ siswa meningkat keper-cayaan, rasa hormat, tanggung jawab, keadilan, peduli dan kewarganegaraan, sebesar $75 \%$ siswa mampu mengubah perilaku mereka sendiri sebagai hasil dari pengajaran karakter, $61 \%$ terjadi peningkatan frekuensi sifat saling membantu, terjadi penurunan frekuensi menyalahkan orang lain $(55 \%)$, dan peningkatan frekuensi kejujuran $50 \%$.
Lickona (1992) menjelaskan beberapa alasan perlunya pendidikan karakter, di antaranya: (1) Banyaknya generasi muda saling melukai karena lemahnya kesadaran pada nilainilai moral, (2) Memberikan nilai-nilai moral pada generasi muda merupakan salah satu fungsi peradaban yang paling utama, (3) Peran sekolah sebagai pendidik karakter menjadi semakin penting ketika banyak anak-anak memperoleh sedikit pengajaran moral dari orangtua, masyarakat, atau lembaga keagamaan, (4) masih adanya nilai-nilai moral yang secara universal masih diterima seperti perhatian, kepercayaan, rasa hormat, dan tanggungjawab, (5) Demokrasi memiliki kebutuhan khusus untuk pendidikan moral karena demokrasi merupakan peraturan dari, untuk dan oleh masyarakat, (6) Tidak ada sesuatu sebagai pendidikan bebas nilai. Sekolah mengajarkan pendidikan bebas nilai. Sekolah mengajarkan nilai-nilai setiap hari melalui desain ataupun tanpa desain, (7) Komitmen pada pendidikan karakter penting manakala kita mau dan terus menjadi guru yang baik, dan (7) Pendidikan karakter yang efektif membuat sekolah lebih beradab, peduli pada masyarakat, dan mengacu pada performansi akademik yang meningkat. Alasan-alasan di atas menunjukkan bahwa pendidikan karakter sangat perlu ditanamkan sedini mungkin untuk mengantisipasi persoalan di masa depan yang semakin kompleks seperti semakin rendahnya perhatian dan kepedulian anak terhadap lingkungan sekitar, tidak memiliki tanggung-jawab, rendahnya kepercayaan diri, dan lain-lain.

Menurut Suyanto (2009), beberapa negara yang telah menerapkan pendidikan karakter sejak pendidikan dasar di antaranya adalah; Amerika Serikat, Jepang, Cina, dan Korea. Hasil penelitian di negara-negara tersebut mengung-kapkan bahwa implementasi pendidikan karakter yang tersusun secara sistematis berdampak positif pada pencapaian akademis.

\section{Hasil Analisis Kurikulum 2013 dan Pembe- lajaran Tematik Terpadu}

Kemendikbud menyatakan bahwa penerapan kurikulum 2013 dilaksanakan secara 
bertahap. Pada tahun pelajaran 2013-2014 ini untuk tingkat SD dilaksanakan pada kelas 1 dan kelas IV. Selanjutnya pada tahun pelajaran 2014-2015 diterapkan pada kelas II dan kelas V. Kelas III dan kelas VI akan mendapat giliran melaksanakan kurikulum 2013 pada tahun pelajaran 2015-2016. Artinya untuk tingkat SD secara total melaksanakan kurikulum 2013.

Hasil analisis kurikulum terhadap pembelajaran tematik terpadu pada kurikulum 2013 mengungkapkan bahwa untuk kelas IV SD terdapat 9 (sembilan) tema dalam pembalajaran tematik terpadu. Kesembilan tema itu adalah (1), Berbagai Pekerjaan, (2) Peduli terhadap Makhluk Hidup, (3) Selalu Berhemat Energi, (4) Indahnya Kebersamaan, (5) Menghargai Jasa Pahlawan, (6) Indahnya Negeriku, (7) Cita-citaku, (8) Daerah Tempat Tinggalku, (9) Makanan Sehat dan Bergizi.

Subtema yang dikembangkan adalah: Keragaman Budaya Bangsaku, Kebersamaan dalam Keberagaman, Bersyukur atas Keberagaman, Macam-macam Sumber Energi, Pemanfaatan Energi Gerak dan Gaya, Hewan dan Tumbuhan di Lingkungan Rumahku, Keragaman Makhluk Hidup di Lingkunganku, Ayo Cintai Lingkungan, Makhluk Hidup di Sekitar Kita, Jenis- jenis Pekerjaan, Barang dan Jasa, Pekerjaan Orang Tuaku, dan Pekerjaan di Sekitarku. Lima tema terakhir belum dijelaskan secara rinci dalam buku guru atau buku siswa.

Mengintegrasikan pendidikan karakter ke dalam pembelajaran tematik terpadu di SD memerlukan strategi, model, media dan teknik tersendiri. Memadukan nilai-nilai karakter kedalam pembelajaran harus dengan perencanaan yang matang, karena tidak semua nilai karakter dapat diinterasikan secara mudah. Nilai-nilai karakter itu berasal dari nilai-nilai luhur universal. Sejak tahun ajaran 2011 Dikbud (sebelumnya: Diknas) mencanangkan penerapan 18 nilai karakter yang harus diintegrasikan dalam pembelajaran seluruh tingkat pendidikan di Indonesia. Kedelapan belas nilai karakter di atas akan menjadi lebih mudah diintegrasikan dalam pembelajaran tematik terpadu karena dalam kurikulum baru 2013 secara umum bersifat holistik terpadu berfokus pada alam, sosial, dan budaya. Ciri khusus lainnya yang memungkinkan adalah memadukan pendidikan karakter dalam pembelajaran tematik terpadu yang menekankan aspek kognitif, afektif, psikomotorik melalui penilaian berbasis test dan portofolio yang saling melengkapi. Penggunaan tema yang merupakan pokok pikiran atau gagasan yang menjadi inti pembicaraan dalam mengaitkan beberapa materi pelajaran dapat memberikan pengalaman bermakna kepada peserta didik. Karateristik pembelajaran seperti itulah yang memungkinkan pendidikan karakter mendapat tempat untuk diintegrasikan dalam pembelajaran tematik terpadu.

Pembelajaran karakter yang terintegrasi dalam mata pelajaran juga tercatat masih baru yaitu pada tahun ajaran 2011. Pada saat itulah nilai 18 karakter yang diperkenalkan kepada sekolah dalam berbagai tingkat untuk dilaksanakan. Tentunya belum begitu banyak penelitian yang dilakukan terkait 18 nilai karakter yang harus diintegrasikan dalam setiap mata pelajaran. Hasil wawancara dengan para guru. Mengungkapkan bahwa selain belum memahami secara mendalam tentang implementasi pembelajaran tematik terpadu dan pendidikan karakter, guru juga belum memiliki kompetensi yang baik tentang penilaian sikap spiritual dan sosial dalam pembelajaran tematik terpadu.

\section{Penilaian Sikap Spritual dan Sosial}

Evaluasi yang dimaksudkan dalam penelitian ini adalah melaksanakan penilaian terhadap sikap yang dibagi dalam dua kompetensi sikap yaitu sikap spiritual dan sikap sosial. Kurikulum 2013 membagi kompetensi sikap menjadi dua, yaitu sikap spiritual yang terkait dengan pembentukan peserta didik yang beriman dan bertakwa, dan sikap sosial yang terkait dengan pembentukan peserta didik yang berakhlak mulia, mandiri, demokratis, dan bertanggung jawab. Pada jenjang SD, kompetensi sikap spiritual mengacu pada KI-1: Menghargai dan menghayati ajaran agama yang dianutnya, sedangkan kompetensi sikap sosial mengacu pada KI-2: Menghargai dan meng-hayati perilaku jujur, disiplin, tanggung jawab, peduli (toleransi, gotong royong), santun, 
percaya diri, dalam berinteraksi secara efektif dengan lingkungan sosial dan alam dalam jangkauan pergaulan dan keberadaannya.

\section{a. Teknik Observasi}

Kemendikbud (2013) menjelaskan bahwa observasi merupakan teknik penilaian yang dilakukan secara berkesinambungan dengan menggunakan indera, baik secara langsung maupun tidak langsung dengan menggunakan pedoman observasi yang berisi sejumlah indikator perilaku yang diamati. Observasi dilaksanakan oleh guru secara langsung tanpa perantara orang lain. Sedangkan observasi tidak langsung dengan bantuan orang lain, seperti guru lain, orang tua, siswa, dan karyawan sekolah.

Teknik penilaian observasi dapat digunakan untuk menilai ketercapaian sikap spiritual dan sikap sosial. Pengembangan teknik penilaian observasi untuk menilai sikap spiritual dan sikap sosial berasarkan pada kompetensi inti kedua ranah ini. Sikap spiritual ditunjukkan dengan perilaku beriman, bertaqwa, dan bersyukur. Sedangkan sikap sosial sesuai kompetensi inti tingkat SD mengembangkan sikap jujur, disiplin, tanggung jawab, peduli (toleransi, gotong royong), santun, dan percaya diri dalam berinteraksi secara efektif dengan lingkungan sosial dan alam dalam jangkauan pergaulan dan keberadaannya. Sikap spiritual dan sikap sosial dalam kompetensi ini dijabarkan secara spesifik dalam kompetensi dasar. oleh karena itu sikap yang diobservasi juga memperhatikan sikap yang dikembangkan dalam kompetensi dasar.

Bentuk instrumen yang digunakan untuk observasi adalah pedoman observasi yang berupa daftar cek atau skala penilaian (rating scale) yang disertai rubrik. Daftar cek digunakan untuk mengamati ada tidaknya suatu sikap atau perilaku. Sedangkan skala penilaian menentukan posisi sikap atau perilaku siswa dalam suatu rentangan sikap.

Pedoman observasi secara umum memuat pernyataan sikap atau perilaku yang diamati dan hasil pengamatan sikap atau perilaku sesuai kenyataan. Pernyataan memuat sikap atau perilaku yang positif atau negatif sesuai indikator penjabaran sikap dalam kompetensi inti dan kompetensi dasar. Rentangan skala hasil pengamatan antara lain berupa:

1) Selalu, sering, kadang-kadang, tidak pernah

2) Baik sekali, baik, cukup baik, kurang baik

Pedoman observasi dilengkapi juga dengan rubrik dan petunjuk pensekoran. Rubrik memuat petunjuk/uraian dalam penilaian skala atau daftar cek. Sedangkan petunjuk penskoran memuat cara memberikan skor dan mengolah skor menjadi nilai akhir. Agar observasi lebih efektif dan terarah hendaknya:

1) Dilakukan dengan tujuan jelas dan direncanakan sebelumnya, perencanaan mencakup indikator atau aspek apa yang akan diamati dari suatu proses.

2) Menggunakan pedoman observasi berupa daftar cek atau skala, model lainnya.

3) Pencatatan dilakukan selekas mungking tanpa diketahui oleh peserta didik

4) Kesimpulan dibuat setelah program observasi selesai dilaksanakan.

\section{b. Teknik Penilaian Diri Sendiri}

Penilaian diri merupakan teknik penilaian dengan cara meminta peserta didik mengemukakan kelebihan dan kekurangan dirinya, penguasaan kompetensi yang ditargetkan, dan menghargai, menghayati serta pengamalan perilaku berkepribadian Jujur, Jujur adalah perilaku yang didasarkan pada upaya menjadikan dirinya sebagai orang yang selalu dapat diper-caya dalam perkataan, tindakan, dan pekerjaan.

Skala Likert adalah skala yang dapat dipergunakan untuk mengukur sikap, pendapat, dan persepsi seseorang atau sekelompok orang mengenai suatu gejala atau fenomena pendidikan. Dalam skala Likert terdapat dua bentuk pernyataan yaitu pernyataan positif yang berfungsi untuk mengukur sikap positif, dan pernyataan negative yang berfungsi untuk mengukur sikap negative objek sikap.

\section{1) Teknik Penilaian diri Terbuka}

Peserta didik mampu untuk menentukan sikap terhadap suatu situasi atau pernyataan yang membutuhkan tanggapan, lengkap dengan 
alasan terhadap pilihannya tersebut. Teknik ini menuntut siswa berani untuk mengungkapkan pendapat pribadi dari masing-masing siswa. Guru bisa memilah jawaban-jawaban siswa yang mampu mengarahkan siswa untuk menentukan pilihan yang posistif dalam hidup mereka.

\section{2) Skala Semantic Differential}

Skala diferensial yaitu skala untuk mengukur sikap, tetapi bentuknya bukan pilihan ganda maupun checklist, tetapi tersusun dalam satu garis kontinum di mana jawaban yang sangat positif terletak dibagian kanan garis, dan jawaban yang sangat negative terletak di bagian kiri garis, atau sebaliknya. Data yang diperoleh melalui pengukuran dengan skala semantic differential adalah data interval. Skala bentuk ini biasanya digunakan untuk mengukur sikap atau karakteristik tertentu yang dimiliki seseorang.

\section{Penilaian Antarteman}

Penilaian antar peserta didik merupakan teknik penilaian dengan cara meminta peserta didik untuk saling menilai terkait dengan pencapaian kompetensi. Aspek kompetensi yang dinilai adalah kompetensi inti spritual yaitu menghargai dan menghayati ajaran agama yang dianutnya, dan kompetesi inti sosial yaitu perilaku jujur, disiplin, tanggungjawab, peduli (toleransi, gotong royong), santun, dan percaya diri.

Instrumen yang digunakan untuk penilaian antarpeserta didik adalah daftar cek dan skala penilaian (rating scale) dengan teknik sosiometri berbasis kelas. Guru dapat menggunakan salah satu dari keduanya atau menggunakan dua-duanya.

Instrumen ini digunakan sebagai cross check terhadap hasil penilaian diri yang dilakukan oleh peserta didik. Daftar cek disusun oleh pihak sekolah dan dapat diperbaiki atau disempurnakan setiap semester. Instrumen daftar cek yang disediakan oleh sekolah sekurang-kurangnya 10 eksemplar untuk setiap peserta didik atau 20\% dari jumlah peserta didik dalam satu rombongan belajar. Peserta didik dinilai oleh teman satu kelasnya.

\section{Jurnal Harian}

Teknik penilain keempat adalah Jurnal Harian. Jurnal merupakan catatan pendidik di dalam dan di luar kelas yang berisi informasi hasil pengamatan tentang kekuatan dan kelemahan peserta didik yang berkaitan dengan sikap dan perilaku. Guru memberikan penilaian kepada peserta didik dengan memberikan deskripsi terhadap sikap dan perilaku peserta didik khususnya berkaitan dengan Kompetensi Inti 1 (yang mencakup menghargai dan menghayati ajaran agama yang dianutnya) dan Kompetensi Inti 2 (yaitu menghargai dan menghayati perilaku Jujur, disiplin, tanggung jawab, peduli (toleransi, gotong royong), santun, percaya diri dalam berinteraksi secara efektif dengan lingkungan sosial dan alam dalam jangkauan pergaulan dan keberadaannya).

Teknik jurnal harian memiliki kelebihan dimana peristiwa/kejadian dicatat dengan segera. Dengan demikian, jurnal bersifat asli dan objektif dan dapat digunakan untuk memahami siswa dengan lebih tepat. sementara itu, kelemahan yang ada pada jurnal adalah reliabilitas yang dimiliki rendah, menuntut waktu yang banyak, perlu kesabaran dalam menanti munculnya peristiwa sehingga dapat menggang-gu perhatian dan tugas guru, apabila pencatatan tidak dilakukan dengan segera, maka objekti-vitasnya berkurang.

Pencatatan peristiwa pribadi dalam jurnal, membutuhkan perhatian khusus dan guru perlu mengenal dan memperhatikan perilaku peserta didik baik di dalam kelas maupun di luar kelas. Aspek-aspek pengamatan ditentukan terlebih dahulu oleh guru sesuai dengan karakteristik mata pelajaran yang diajar. Aspek-aspek pengamatan yang sudah ditentukan tersebut kemudian dikomunikasikan terlebih dahulu dengan peserta didik di awal semester.

Beberapa hal yang perlu diperhatikan dalam membuat jurnal adalah: (1) catatan atas pengamatan guru harus objektif, (2) pengamatan dilaksanakan secara selektif, artinya yang dicatat hanyalah kejadian/peristiwa yang berkaitan dengan Kompetensi Inti, dan (3) pencatatan segera dilakukan. 
Pedoman umum penyekoran jurnal: (1) penyekoran pada jurnal dapat dilakukan dengan menggunakan skala likert. Sebagai contoh skala 1 sampai dengan 4. Bisa juga guru membuat rentang skala 5, ataupun 7, (2) guru menentukan aspek-aspek yang akan diamati, (3) masingmasing aspek, guru menentukan indikator yang diamati, (4) setiap aspek yang sesuai dengan indikator yang muncul pada diri peserta didik diberi skor 1, sedangkan yang tidak muncul diberi skor 0, (5) jumlahkan skor pada masingmasing aspek, (6) skor yang diperoleh pada masing-masing aspek kemudian direratakan, (7) nilai Sangat Baik (SB), Baik (B), Cukup (C), dan Kurang (K).

\section{SIMPULAN}

Pendidikan karakter yang diintegrasikan dalam kurikulum 2013 merupakan upaya pemerintah dalam meningkatkan dan membangun karakter bangsa yang lebih baik di masa datang. Pembelajaran tematik terpadu yang dipilih untuk dilaksanakan di SD dari kelas I sampai kelas VI merupakan keputusan yang sangat tepat untuk mengoptimalkan pendidikan karakter di sekolah. Menggunakan tema dalam setiap kegiatan pembelajaran memungkinkan peserta didik dapat menerima informasi lebih konkrit dan konteks-tual.

Pembelajaran tematik terpadu dalam kurikulum 2013 mengintegrasikan sikap spiritual $\left(\mathrm{KI}_{1}\right)$, sikap sosial $\left(\mathrm{KI}_{2}\right)$, pengetahuan $\left(\mathrm{KI}_{3}\right) \quad$ keterampilan $\left(\mathrm{KI}_{4}\right)$. Pembelajaran diarahkan pada pemerolehan pengetahuan dan keteram-pilan, namun sekaligus memberikan penilaian terhadap sikap. Penilaian sikap dilakukan dengan empat teknik penilaian yaitu (1) teknik obser-vasi, (2) penilaian diri sendiri, (3) penilaian antar teman, (4) jurnal harian. Teknik penilaian ini membutuhkan perhatian khusus dari para guru, karena pada kurikulum sebelumnya belum dilakukan. Guru perlu pendalaman melalui pelatihan-pelatihan yang memadai agar objeti-vitas penilaian dapat dilakukan secara optimal.
Kemendikbud. 2013. Pedoman Penilaian Sikap. Jakarta: Puskur

Kemendikbud. 2013. Kurikulum 2013. Jakarta: Puskur

Lickona, T. 1991. Educating For Character. New York: Bantam

Marvin, B. 2005. What Works In Character Education: A research-driven guide for educators. St Louis: University of Missouri

Saryono, D. 2010. "Penyusunan Rencana Tindakan Implementasi Pendidikan Karak-ter Bangsa di Sekolah”. Makalah Training of Trainers Pengintegrasian Pendidikan Budaya dan Karakter Bangsa dalam Pembelajaran, Dinas Pendidikan Provinsi Jawa Timur.

Sever, A.U.S. 1997. No laughing matter: Boundariesof gender-based humour in the classroom. Journalof Higher Education, 68(1): 87-105.

Several of the points made in this section are taken from the article "What's Right and Wrong In Character Education Today" by Eric Schaps, Esther F. Schaeffer, and Sanford N. McDonnell (Education Week On The Web, Sept. 12, 2001.

Susan, F., et.al .2004. The Impact of Character Education Curricula on Youth Educators Journal of Leadership Education Vol. 3. Issue 3

Suyanto. 2009. Urgensi Pendidikan Karakter . Jakarta: Direktorat Jenderal Manajemen Pendidikan Dasar dan Menengah.

Wibowo,T. 2013. Pendidikan Karakter untuk Anak.

http://www.pendidikankarakter.com/diaks es tanggal 10 Maret 2013

Van, W. M.M. 2008. Module ECT 122-Study Guide on Teaching Methods and Media for the Post Graduate Certificate in Education for Further Education and Training Phase. Bloemfontein: University of the Free State 